\title{
IPOSTAZE THANATICE ÎN POETICA LUI LUCIAN BLAGA ȘI DYLAN THOMAS
}

\section{Universitatea de Vest din Timisoara}

The following paper revolves around the concept of thanatos, whose name comes from the personification of death in the Greek mythology. In other words, the objective of this paper is to analyze the main forms and symbols regarding the theme of death in several poems of Lucian Blaga and Dylan Thomas and try to explain how, despite the fact that they come from different cultural environments and have different sources of inspiration and literary purposes regarding the aim of their works, their poetical works present several resemblances in terms of meaning in relation to the theme of death, as approached in the 20th century modern poetry.

Keywords: death, thanatic, body, transcendence, being

Privind retrospectiv asupra literaturii secolului $\mathrm{XX}$, atât în spațiul european, cât și în cel românesc, vom constata o schimbare majoră de paradigmă atât la nivelul semnificațiilor și simbolisticii în genere, cât și asupra ideii de literatură per ansamblu. Un secol măcinat de crize, manifestări ideologice radicale și două războaie mondiale a condus, în cele din urmă, la un fenomen de reorganizare structurală și identitară a literaturii în sine, iar poezia modernă a devenit, asemeni artei în general, oglinda unei lumi tot mai bulversate în propria-i autodistrugere. În „Structura liricii moderne”, de pildă, Hugo Friedich aduce în prim-plan ideea unui „dramatism agresiv al poeziei moderne" (Friedrich, 1998: 14), dramatism care se reflectă în special printr-o reconfigurare a viziunii asupra marilor probleme de natură existențială, precum și asupra modului în care poezia se exprimă atât pe sine, cât și pe spațiul din jurul său, în raport cu noul perspectivism. Astfel, în ciuda caracterului multifațetat pe care modernismul îl manifestă prin multiplele sale schimbări, de la simbolism până la expresionism sau ermetism - redând aici teoria lui Radu Vancu, potrivit căreia ,poezia reprezintă ieșirea din întunericul indistinct al neantului la viziunea pură; iar această viziune se produce prin medierea unui poem înțeles ca o structură formală perfect supravegheată și etanșeizată" (Vancu, 210) - putem vorbi, într-o oarecare măsură, despre niște elemente comune care se regăsesc sub spectrul larg și complex pe care modernismul îl oferă spre analiză, elemente care, la nivel ideatic, readuc poezia modernă sub auspiciile unor mecanisme aproape identice de funcționare și care, cel puțin la nivel teoretic, stau sub semnul unor asemănări mai mult sau mai puțin vizibile.

Astfel, ajungem și la demersul pe care lucrarea de față își propune să îl efectueze în următoarele capitole. În acest caz, vorbim despre doi poeți care, 
la prima vedere, sunt total diferiți, atât ca manifestare poetică, dar și în ceea ce privește viziunea asupra artei în sine. Avem, așadar, de-a face cu doi poeți situați la poli relativ opuși: vorbim despre un poet român, a cărui poezie a fost încadrată, în cea mai mare parte, sub semnul expresionismului, precum și un poet galez, pe care critica literară a decis să îl considere ca fiind de sorginte simbolistă. Desigur, trecând dincolo de aceste clasificări standardizate, întrucât este dificil şi, mai ales, improprie o astfel de ,încadrare" în limitele unui singur curent literar, avem de-a face cu doi poeți a căror activitate a presupus perspective diferite, aflați în spații diferite și având influențe diferite. Însă ceea ce îi aduce pe aceștia într-un punct comun, care poate reprezenta elementul unei analize comparative este o temă de o importanță semnificativă în lirica moderă, o tematică a cărei reprezentări, în linii mari, pornește din același punct. Vorbim aici, așadar, despre tema morții și a reprezentărilor de factură thanatică pe care le întâlnim în lirica modernă și nu numai, temă care pune, astfel, în prim-plan scopul și necesitatea lucrării de faţă. Prin analiza pe care urmează să o efectuăm în subcapitolele următoare, obiectul acestei lucrări constă în a compara câteva ipostaze thanatice care se regăsesc în lirica lui Lucian Blaga, respectiv a lui Dylan Thomas și de a observa principalele asemănări și deosebiri care apar în ceea ce privește atât viziunea asupra morții, cât și a poeziei moderne per ansamblu, urmând să demonstrăm că, desi sunt situați la poli diferiți, cei doi poeți pot fi cuprinși într-o analiză comparativă și prezintă elemente comune la nivelul construcției ideatice pe care poezia lor șio propune în raport cu viziunea asupra morții la nivelul întregului modernism.

\section{Moartea de tip ontologic și universalitatea corporalului}

Înainte de a începe o analiză propriu-zisă a ipostazelor thanatice în opera lui Blaga, respectiv a lui Thomas, se cuvine să abordăm problematica thanatosului din perspectivă psihologică. Ion Biberi, de pildă, susține un punct de vedere care situează moartea într-o sferă a individualului ireductibil: „atitudinea în fața morții nu e o manifestare periferică și neaderentă adâncului sufletesc individual, ci e o trăsătură capitală a acestuia, indicând, prin corelația ei cu celelalte date sufletești, întreaga structură a individualității. Atitudinea în fața morții exprimă deci viața individualității umane în ce are mai ireductibil" (Biberi, 2000: 27). Cu alte cuvinte, acesta sugerează faptul că moartea implică în mod direct o componentă individuală supremă, iar thanatosul implică, de fapt, o componentă fenomenologică la nivelul existenței, caracterul său ireductibil reprezentând eidosul vieții individualității umane. Moartea, aşadar, apare definită aici atât drept un punct proxim al existenței din punct de vedere fenomenologic, cât și unul dintre aspectele fundamentale în ceea ce privește caracterul ontologic al vieții. Caracterizată de către Eugen Todoran ca fiind născută ,dintr-o abstractizare $a$ realității, redusă la ființă " (Todoran, 1997: 145), moartea capătă noi valențe în poezia modernă, care se reflectă și în peisajul poetic românesc. Despre 
conceptul de thanatos în universul liric blagian, Mihai Cimpoi afirmă, în volumul Lucian Blaga. Paradisiacul. Lucifericul. Mioriticul, faptul că „moartea este una filosofică, ,ontologică”, este proiecția senzațiilor și simțurilor alterate, uscate (degradate fizic), îmbătrânite - am putea spune depanizate și, firește, a unei mutațiuni fundamentale survenite în reprezentarea lumii: ea este o poveste" (Cimpoi, 1997: 23). Așadar, această criză ontologică manifestată la nivelul liricii blagiene survine drept o consecință a manifestării thanatice la nivel micro și macrocosmic. Moartea simţurilor, precum și alteritatea care se instaurează la nivelul reprezentării lumii

$O$ viziune asemănătoare a fost observată, de-a lungul timpului, și în poetica lui Dylan Thomas. Radu Vancu, unul dintre foarte puținii critici care au vorbit despre opera poetului galez în spațiul românesc, tratează în Elegie pentru uman o problematică a corporalului în poetica lui Thomas, mizând pe unul dintre cele mai importante aspecte din poezia acestuia, și anume relaţia dintre corporal și dimensiunea umană, idee obsedantă pentru Dylan Thomas, care înţelege prin ideea de corporalitate însăşi o reprezentare antropocentrică a artei, precum și o condiție esențială a poeziei moderne: „însă ceea ce-1 individualizează pe Thomas [...] e că, departe de a respinge umanul, cu „căldura animală" și cu emoția lui, e ataşat de ele monomaniacal, obsedant, la fel ca toți marii corporali care se opun din răsputeri evacuării omului din centrul artei”. (Vancu, 2016: 245).

Însă una dintre cele mai inedite viziuni asupra corporalității în opera lui Dylan Thomas o oferă John Goodby, care situează ideea de corporalitate la un nivel microcosmic, pe care Dylan Thomas o universalizează: „Consider că Thomas nu a fost interesat de o reconciliere bazată pe credință, ci mai mult de o posibilitate prin care materialul și spiritualul să fuzioneze, în special după cum se poate observa la nivel microcosmic, cu corpul uman drept Universul" (Goodby, 2013: 66). După cum se poate observa, în vreme ce, în poetica lui Blaga, ideea morții e construită drept un procedeu ontologic care vizează trecerea dinspre dimensiunea umană spre macrocosmos, în poezia lui Dylan Thomas vom observa că ideea morții, așa cum a teoretizat-o Goodby, survine la nivel microcosmic, în care paradigma umanului este, de fapt, o reprezentare a întregului univers, ambele dimensiuni având în prim-plan perspectiva thanatică drept punct de plecare. Dacă Blaga mizează pe moartea drept ieșire din ființă, la Dylan Thomas moartea reprezintă o întoarcere la aceasta. Atât în opera lui Blaga, cât și în cazul lui Thomas, moartea nu reprezintă un sfârşit, ci o reîntoarcere.

\section{Transcendență și transdescendență}

De-a lungul deceniilor, despre poezia lui Lucian Blaga s-a vorbit, în majoritatea cazurilor, dintr-o perspectivă care viza în mod exclusiv o

\footnotetext{
${ }^{1}$ Traducerea îmi aparține.
} 
componentă transcendentală. În nenumărate studii critice, universul poetic blagian a fost configurat îndeosebi sub spectrul unui puternic filon de natură metafizică - uneori justificat, alteori mai puțin - care viza o depăşire întru totul a spațiului terestru, concret și încercarea de a accede (paradoxal sau nu, prin mister) la tainele supreme ale universului. $\mathrm{Nu}$ de puține ori, Blaga a fost considerat un mistic, un mitic şi un poet religios, însă ceea ce, în repetate rânduri, a fost trecut cu vederea a fost dimensiunea umană a acestei ,evadări” înspre transcendent. Din această perspectivă, moartea a fost trecută adeseori în plan secund, important fiind, în viziunea criticilor, scopul final, acela de a înțelege tainele Marelui Anonim și, totodată, de a potenţa caracterul încifrat al universului liric blagian. Însă viziunea asupra morții în poetica blagiană capătă noi sensuri odată ce începem să privim acest fenomen al transcendenței în raport cu elementul său de intensitate egală, însă de sens opus. Discutând despre metafizica poeziei lui Blaga, Eugen Todoran remarcă o dimensiune a transcendentalului care se opune accederii înspre zonele ,superioare" ale existenței - reluând astfel criza ontologică din subcapitolul anterior - şi mizează pe conceptul de transdescendență, teoretizat de Michel Piclin în $L a$ notion de transcendence pentru a ilustra caracterul antropocentric și dimensiunea umană prin care thanatosul, sub formele sale, este conceptualizat în universul poetic blagian: „transcendența, ca transcendență, are sensul divinului, precum transcendența ca trans-descendență are sensul umanului. $\mathrm{Cu}$ observația că și pentru el primul caracter ce se atribuie termenului de transcendent este superioritatea, într-o viziune ce s-ar putea numi verticala transcendenței, constituind totodată sursa unor mari întrebări cu privire la condiția absolută a transcendenței. (Todoran, 1997: 129)

Aceeași tematică a transdescendenței se regăsește și în poetica lui Dylan Thomas, cu o serie de câteva diferențe. Mizând, de asemenea, pe o dimensiune antropocentrică în detrimentul uneia metafizice, acesta observă faptul că opera poetului galez se bazează pe o idee de corporalitate care nu numai că transcende moartea (şi o învinge), ci mai mult decât atât, în loc să tindă spre stadiul superior, spre transcendent, spre Marele Anonim și spre tainele Universului, înțelege moartea ca fiind taina supremă și tinde, în mod paradoxal, spre aceeași transdescendență: „Moartea nu e un punct terminus pentru el; el coboară în mormânt și suferă strania și secreta existenţă a morții, suferă fermitatea corpului în elementele sale și transmutarea acestora în alte forme ale vieții. El poate privi înapoi spre viaţă așa cum doar un mort ar putea, și poate să se ridice din mormânt. Creaţia și Catastrofa cea din urmă nu îl limitează; el pătrunde în tainele minții lui Dumnezeu înaintea Creației și poate simți ce ar fi simțit de către particulele împrăștiate ale universului complet dizolvat" (Olson, 1954: 13).

\footnotetext{
${ }^{2}$ Traducerea îmi aparține.
} 


\section{De la cântecul marii tăceri la maligna vitalitate}

Dacă, în subcapitolele precedente, ne-am axat mai mult asupra unei analize a criticii literare care aborda problematica thanatosului în operele celor doi poeți, vom dedica următoarele două subcapitole unei analize ceva mai detaliate asupra câtorva poeme ale lui Lucian Blaga, respectiv ale lui Dylan Thomas, pentru a putea observa modul în care toate aceste elemente pe care leam prezentat anterior se îmbină pentru a configura această problematică a morții în opera celor doi poeți moderni. În acest subcapitol vom analiza, din opera poetică a lui Lucian Blaga, câteva poeme din volumul În marea trecere. Înainte de a trece la analiza propriu-zisă, vom porni de la următoarea definiție oferită de Mihai Cimpoi pentru a ilustra ideea de cântec în raport cu moartea în poezia blagiană: „Cântecul ființei e convertit, în ansamblu, într-un cântec al neființei, desferecat din mormintele strămoșilor [...] Cântecul, îndreptat dinspre Ființă înspre Neființă, sfârșește în tăcere, într-un demers modern tulburător [...]. Marea trecere este marea tăcere, la Blaga. Celor ce așteaptă să vorbească, poetul le-ar putea vorbi despre orice [...]. Or, înainte de toate, el le este dator cu rostirea esențială despre Ființă, despre marea trecere și cuvintele [...] se neantizează cu de la sine putere, se autoreduc la necuvinte recăzătoare în tăcerea increatului verbal și sincronizat perfect cu căderea Ființei însăși în increatul cosmic" (Cimpoi, 1997, 24).

În cazul poeziei lui Dylan Thomas se remarcă o componentă malignă a universului poetic, una în care thanaticul se reconfigurează în jurul ideii de moarte şi unde aceasta determină o „renaștere” a întregului spectru al vieții: „semnificația lui Thomas, plasată într-un univers neutru [...] este una aproape în întregime malignă, în care toate ființele umane sunt cândva vii și hrănesc focurile procesului, efectiv morții vii [...] unde Universul ca logos este reînceput de fiecare dată când concepția se petrece"33 (Goodby, 2013, 78). Thomas privește moartea drept „existența ca tragicul conștiinței autoconsumării, în opoziție cu un echilibru empiric și gradual al vieții împotriva morții, cu moartea întotdeauna, în mod inevitabil, înclinând balanța"4 (Ibidem: 82). $\mathrm{Nu}$ în ultimul rând, moartea are, în mod aproape paradoxal, o funcție vitală în opera poetului galez, așa cum am observat anterior. Thanatosul se prezintă sub forma unei vitalități a morții, precum și a unui proces de vitalizare om-natură care nu doar potențează, ci și amplifică această trăsătură a dimensiunii morții: „Thomas identifică procesul de vitalizare în ființă și pe cel de vitalizare în natură: ambele sunt subiectul aceleiaşi vieți și aceleiași morți." ${ }^{5}$ (Ackerman, 1996: 44).

\footnotetext{
${ }^{3}$ Traducerea îmi aparține.

${ }^{4}$ Traducerea îmi aparține.

${ }^{5}$ Traducerea îmi aparține.
} 


\section{Între lauda somnului și noaptea cea fatidică}

După cum se poate observa în titlul acestui subcapitol, ne vom îndrepta atenția aici asupra câtorva poeme din volumul Lauda somnului, urmând a le compara cu poemul despre care mulți l-au considerat cel mai prolific pe care Dylan Thomas 1-a oferit literaturii, și anume villanela Do not go gentle into that good night. Înainte de a începe analiza propriu-zisă, ne vom concentra atenția asupra câtorva elemente din critica literară, care ilustrează tragismul rezultat în poetica lui Blaga în cadrul acestui volum: „Nucleul sentimentului tragic se află în contradicția dintre lumea unor armonii sublime și a desăvârşirii către care tinde poetul și lumea scindată lăuntric, degradată ontologic" (Tănase, 1977: 348). Dacă problematica dimensiunii ontologice în poetica blagiană a fost deja abordată în subcapitolele anterioare, problematica tragismului, în schimb, se configurează pe baza unui concept pe care îl vom întâlni și în villanella lui Dylan Thomas, și anume contradicția dintre armonii şi degradarea de tip ontologic. În cazul de față, după cum vom observa și atunci când vom trece la analiza textelor, tragismul sentimentului morții se construiește pe baza unei contradicții care determină un conflict lăuntric moartea devine, aşadar, o luptă, un impediment și un dezechilibru care cauzează o tensiune generatoare de patos existențial desăvârşit.

În termeni asemănători vom face referire și la poemul lui Dylan Thomas, unul care, într-o mare măsură, funcționează pe baza aceluiași „mecanism”. Ralph Maud afirmă că „Thomas ar trebui să primească credit pentru justa exprimare a dogmei fundamentale a non-religiosului: aceea că intelectul nu poate suporta faptul morții, și asprimea, rebeliunea, ura, regretul de sine, compasiunea - emoția pură - cu care nouă ne rămâne să facem față

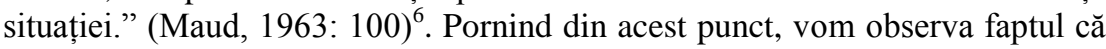
Do not go gentle into that good night tratează tocmai această problematică a tragismului morții în raport cu refuzul acceptării acesteia. Patosul se configurează conform acelorași coordonate, iar conform lui John Goodby, „Ceea ce într-adevăr distruge «sufletul» (înțeles mai degrabă drept spirit sau imaginație decât în sens creștin) este „revolta” unei viitoare voințe dominatoare împotriva acestor limite. Pentru a nega moartea, care este în mod inextricabil legată de viață, e necesar a nega procesul și unitatea"7 (Goodby, 2013: 76).

\section{Concluzii}

Pentru a conchide cele afirmate anterior în lucrarea de față, putem afirma că atât în poezia blagiană, cât și în cazul operei lui Dylan Thomas putem vorbi despre o poetică a corporalului și, mai mult decât atât, despre o poetică a umanului, ambele având în prim-plan perspectiva thanatosului. Deși

\footnotetext{
${ }^{6}$ Traducerea îmi aparține.

${ }^{7}$ Traducerea îmi aparține.
} 
perspectivele de abordare sunt diferite, iar maniera de interpretare a acesteia, fie ea simbolistă ori expresionistă, se supune unor direcții care nu coincid în mod evident, putem afirma că demersul hermeneutic întreprins în lucrarea de față, unul aparent eclectic, se poate susține și poate fi validat atunci când facem referire la opera poetică a celor doi drept una a morții privită ca o revitalizare a sinelui, pe de o parte și de redescoperire a coordonatelor existențiale, de cealaltă parte. Astfel, putem afirma că modernismul perspectivei thanatice în poetica lui Lucian Blaga, cât și a Dylan Thomas se configurează pe un sistem referențial care include atât o criză la nivel ontologic, o problematică a transcendenței și, nu în ultimul rând, o rebeliune a sinelui în raport cu dimensiunea biologică și umană, astfel încât ieșirea din ființă conduce, într-un final, la întoarcerea în acelaşi punct proxim și, cel mai important, de un inevitabil absolut necesar.

\section{Bibliografie}

ACKERMAN, John, Dylan Thomas - His Life and Work, third edition, London, Palgrave Macmillan UK, 1996.

BIBERI, Ion, Thanatos : Psihologia morţii, prefaţă de acad. Constantin Bălăceanu-Stolnici, Bucureşti : Curtea Veche, 2000.

BLAGA, Lucian, Poemele luminii - Poezii, Vol. 1, ediție îngrijită de George Ivașcu, Prefață de Mircea Tomuș, Bucureşti : Editura pentru Literatură, 1968.

CIMPOI, Mihai, Lucian Blaga - paradisiacul - lucifericul - mioriticul : poem critic, Cluj-Napoca, Dacia, 1997.

FRIEDRICH, Hugo, Structura liricii moderne : de la mijlocul secolului al XIX-lea pînă la mijlocul secolului al XX-lea, în româneşte de Dieter Fuhrmann, prefață de Mircea Martin, București, Univers, 1998.

GOODBY, John. The poetry of Dylan Thomas: Under the spelling wall, Liverpool University Press, 2013.

MAUD, Ralph, Entrances to Dylan Thomas poetry, London, Scorpion Press, 1963.

OLSON, Elder. The poetry of Dylan Thomas, Chicago, London, The University of Chicago Press, 1965.

TĂNASE, Alexandru, Lucian Blaga - filosoful poet, poetul filosof, Bucureşti, Cartea Românească, 1977.

THOMAS, Dylan, Dylan Thomas selected poems, 1934-1952, London, New Directions Publishing, 2003.

TODORAN, Eugen, Lucian Blaga : mit, poezie, mit poetic, Bucureşti, Grai şi suflet - Cultura Naţională, 1997.

VANCU, Radu. Elegie pentru uman: O critică a modernității poetice de la Pound la Cărtărescu, București, Humanitas, 2016. 